\title{
Digital Influence: Technology and Unpublished Opinions in the Federal Courts of Appeals
}

\author{
Kirt Shuldberg $\dagger$
}

TABLE of Contents

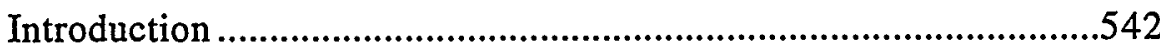

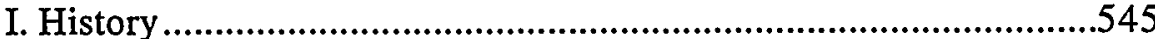

A. Historic Rationale for Selective Publication ............................547

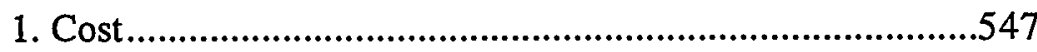

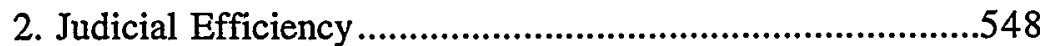

B. Historic Rationale for Prohibiting Citation to

Unpublished Opinions...........................................................549

II. The Problem: Behavior of Judges and Litigants Demonstrates

That Unpublished Does Not Mean Unimportant ........................551

III. A Critique of Historic Rationale in Light of Current Technology ....................................................................556

A. The Selective Publication Argument Revisited.........................557

1. Storage Costs .......................................................................558

2. Research Costs.............................................................559

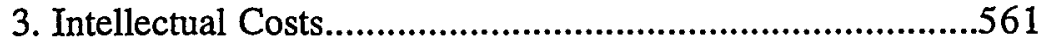

B. The No-Citation Rationale Revisited .....................................563

IV. Fundamental Decisions in Crafting Citation Policy......................566

A. Whether to Allow Electronic Dissemination of

Unpublished Opinions...........................................................566

1. Access Inequity ....................................................................566

2. Judicial Accountability ...................................................567

3. Informational Importance..................................................567

B. Circuit Rules on Citation to Unpublished Opinions..................569

V. A Model Rule ............................................................................570

Copyright $\odot 1996$ Califormia Law Review

$\dagger$ B.S. 1992, Brigham Young University; J.D. candidate 1997, Boalt Hall School of Law, University of California, Berkeley. My thanks to Professor Bob Berring for his helpful guidance throughout; to Elise Crawford, Nan Joesten and my other friends and colleagues on the California Law Review for their diligent and thoughtful editing; to my parents for their example and encouragement; and especially to Lisa for her selflessness, patience and love. 
A. Electronic Dissemination Should be Allowed ........................571

B. Citation to Unpublished Opinions Should Be

Allowed When No Published Opinion Would Serve as Well...571

C. Unpublished Opinions Should Be Given Persuasive Authority 573

Conclusion

.574 


\title{
Digital Influence: Technology and Unpublished Opinions in the Federal Courts of Appeals
}

\author{
Kirt Shuldberg
}

For centuries scholars have lamented the rapidly expanding collection of case law, fearing that storing and processing this information would eventually become impossible. In the early 1970s, in response to these concerns, the Federal Circuits developed and implemented a variety of plans limiting publication to relatively few of the thousands of opinions they produced each year, and restricting citation to unpublished opinions. Limiting publication has had several benefits. First, costs are reduced and fairness increased: the fewer opinions published, the lower the cost of legal research and the less significant disparities in resources are in determining legal outcomes. And, judicial efficiency is increased: because judges need not spend time perfecting opinions that will not be published, they have more time to spend on those that will be. However, this Comment argues, time has shown that unpublished does not necessarily mean unimportant; unpublished opinions are frequently used even if citation to such opinions is prohibited. Moreover, with the advent of the computer, the world of legal research has changed dramatically. Accordingly, this Comment critically examines the original justifications for limiting the publication of federal appellate opinions, concluding that many of the limited publication/nocitation plans currently in use are suboptimal in light of modern digital storage and research capabilities. Finally, the Comment proposes a solution in the form of a model rule focusing on setting appropriate guidelines for the availability and citation of unpublished opinions.

\section{INTRODUCTION}

Each generation, our courts struggle to devise means of coping with an ever-increasing case load. ${ }^{1}$ For federal appellate courts, one remedy has been to publish only selective judicial opinions, and prohibit citation to unpublished opinions. For more than twenty years,

1. In 1994, the federal appellate court system faced 48,815 cases, an increase from 23,200 in 1980 and 40,898 in 1990. U.S. DeP' $T$ of COMmerce, Sta tistical Abstract of the United STATEs 213 (115th ed. 1995) [hereinafter Statistical Abstract]. 
each of the federal circuits has devised and administered its own plan toward that end. Justifications supporting the structure and content of these plans, developed in the early 1970s, were premised on a system of legal information found almost exclusively on the printed page. ${ }^{2}$ Today, however, legal information can be stored, accessed and retrieved in digital form including on-line subscription services, such as Westlaw and Lexis, CD-ROM, and the Internet. Because information is the "stuff" of law, ${ }^{3}$ this change in technology has had a profound impact on the law's shape as well as its use. As one scholar has noted:

[I]nformation technology is different [from other technological advances] and presents the law with a very different kind of challenge. 1t is different because ... the law runs on information and because much of law is information. Thus, all of law is not affected by the automobile because law is not composed of automobiles. But law is, in almost all its parts, dependent on communication and information. ${ }^{4}$

The digital availability of information directly impacts both what it means for an opinion to be "unpublished" and the rationale supporting the content of existing limited publication plans. When the printed volume was the sole source of law, the decision not to publish an opinion meant that the public did not have access to that opinion. Now, however, opinions that are not published in print are nevertheless made available to the public in digital format. Moreover, digital technology allows for more efficient storage and research of information, which impacts the rationale underlying the limited publication plans.

In this Comment, 1 seek to critically examine these existing limited publication/no-citation plans, which are tied to an older, less powerful and less interactive means of communication, and to challenge the applicability of these plans to the changed circumstances of today's digital world. I first provide a brief history of selective publication, examining the historic rationales for the decision to limit publication and restrict citation. I then revisit these rationales and concerns in light of current technology, focusing on theoretical as well as practical limits of existing plans. From there, I examine several possible solutions. Finally, I propose a model rule.

2. See infra text accompanying notes 66-73.

3. See Robert C. Berring, Legal Research and Legal Concepts: Where Form Molds Substance, 75 CALIF. L. REv. I5, 17 (1987) (noting Christopher Columbus Langdell's belief that law books and common law decisions were the very "stuff" of law).

4. M. EThan Katsh, Law in a Digital World 7 (1995). 


\section{I}

\section{HisTORY}

Complaints about the proliferation of case law are not a new phenomenon. Generation after generation of commentators has feared rapidly expanding case law and made dire predictions of the possible effects. ${ }^{5}$ More than three and a half centuries ago, Sir Francis Bacon, then Lord Chancellor, recommended to King James I that cases "merely of iteration and repetition" be omitted from the case reports. ${ }^{6}$ The author of an 1824 article complained:

[T] he multiplication of reports, emanating from the numerous collateral sources of jurisdiction, is becoming an evil alarming and impossible to be born [sic].... Such has been this increase, that very few of the profession can afford to purchase, and none can read all the books which it is thought desirable, if not necessary to possess. By their number and variety they tend to weaken the authority of each other, and to perplex the judgment. ${ }^{7}$

A century later, another commentator, astounded at the growth rate of case law, noted that "[s]ixty-five thousand precedents [had been] added to the already existing myriads of precedent in the brief space of five years!"8 This jurist then lamented:

The law library of the future staggers the imagination as one thinks of multitudes of shelves which will stretch away into the dim distance, rank upon rank, and tier upon tier, all loaded with their many volumes of precious precedents. One shrinks from the contemplation of the intellectual giants who will be competent to keep track of the authorities and make briefs in those days; they, as well as the judges who pass upon the briefs, must needs be supermen indeed. ${ }^{9}$

5. There was a time when such complaints were heard frequently enough that one commentator was motivated to observe: "The prolixity of critiques on this subject tempts the impish suggestion that eventually lawyers may seek a symposium on how to reduce the number of articles devoted to reducing the number of judicial opinions." John J. O'Connell, A Dissertation on Judicial Opinions, 23 TEMP. L.Q. 13, 14 n.3 (1949).

6. Id. at 14 .

7. E. Bliss \& E. White, The Common Law, 10 N. AM. REv. (n.s.) 411, 433 (1824), quoted in J. Myron Jacobstein, Some Reflections on the Control of the Publication of Appellate Court Opinions, 27 Stan. L. Rev. 791, 791 (1975). For an insightful history of the evolution of the case reporter, see Berring, supra note 3 , at 15-22.

8. John B. Winslow, The Courts and the Papermills, 10 ILL. L. REv. 157, 158 (1915) (noting the explosion in reported decisions from 1909 to 1913). To put this in perspective, Lord Coke had similarly complained about the existence of too much precedent at a time when there existed an estimated 30 volumes of case law. Edward H. Warren, The Welter of Decisions, 10 ILL. L. REv. 472, 472 (1916).

9. Winslow, supra note 8 , at 158. 
William Holdsworth, another scholar of the early 1900s, asserted that limiting the number of reported cases was "a condition precedent for the satisfactory working" of a common law system."

Given that commentators complained that the publication of 65,000 cases in five years was an unmanageable mass, it is unsurprising that similar protests are heard today. A jurist of our generation, noting the limited capacity of judges and lawyers to research and assimilate the mass of judicial opinions, commented that " $[\mathrm{t}]$ hose limits are dangerously near at present and in some systems may already be exceeded," and that "[c]ommon law in the United States could be crushed by its own weight if present trends continue unabated."

Despite criticisms like these, however, federal appellate courts continued to authorize publication of virtually every opinion well into the 1960 s and 70s. ${ }^{12}$ Even one-word Memorandum Decisions were published. ${ }^{13}$ In 1964, the Judicial Conference of the United States expressed its concern about the "ever increasing practical difficulty and economic cost of maintaining accessible private and public law library facilities ...."14 Accordingly, the Judicial Conference recommended that the United States Courts of Appeals authorize publication of "only those opinions which are of general precedential value ...." In 1972, endorsing the detailed recommendation made earlier that year by the Board of the Federal Judicial Center, the Judicial Conference directed the circuits to develop plans to limit publication of judicial opinions. ${ }^{16}$ Each circuit responded by devising its own publication plan. According to the Judicial Conference, this diversity in plans constituted " 11 legal laboratories accumulating experience and amending their publication

10. William Searle Holdsworth, Some Lessons From Our Legal History 22 (1928). (1972).

11. Charles W. Joiner, Limiting Publication of Judicial Opinions, 56 Judicature 195, 195-96

12. See, e.g., Donald R. Songer, Criteria For Publication of Opinions in the U.S. Courts of Appeals: Formal Rules Versus Empirical Reality, 73 JUDICATURE 307, 308 (1990) (noting that "[i]t is not known how many decisions of the courts of appeals were not published before 1964, but apparently the number was relatively small").

13. Memorandum Decisions were included at the end of the Federal Reporter volumes. See, e.g., Livesay Industries, Inc. v. Rinehart, 270 F.2d 953, 953 (5th Cir. 1959) (mem.) (holding simply that the judgment of the lower court was "[a]ffirmed").

14. Report of the Proceedings of the Judicial Conference of the United States 11 (1964) [hereinafter 1964 REPORT].

15. Id.

16. See Report of the Proceedings of the Judicial Confirence of the United States 33 (1972). For a more detailed account of this history, see Donna StIENSTRA, Federal Judicial Center, Unpublished Dispositions: Problems of Access and Use in the Courts of Appeals 5-14 (1985); William L. Reynolds \& William M. Richman, An Evaluation of Limited Publication in the United States Courts of Appeals: The Price of Reform, 48 U. CHI. L. REv. 573, 577. 79 (1981). 
plans on the basis of that experience."17 Because the Judicial Conference saw the possible rewards of such experimentation as "rich," it agreed to delay prescribing further guidance. ${ }^{18}$ Today, after more than twenty years of such "rich" experimentation, diverse circuit plans still exist, and the several circuits continue to administer their individually devised publication and citation plans.

These plans involve two key issues: (1) whether and how to limit publication; and (2) whether to allow future parties to cite to unpublished opinions. Following this structure, I will first examine the concerns underlying the decision to publish selectively. I will then address the related issue of prohibiting citation to those decisions that have not been published.

\section{A. Historic Rationale for Selective Publication}

As noted, the decision to publish selectively was primarily driven by a generalized fear of the exponential growth in case law. Underlying this generalized fear are a number of more specific concerns. I have identified two categories under which to discuss these issues: (1) cost concerns and the underlying issue of fairness; and (2) concerns of judicial efficiency. I will briefly outline each of these concerns below and will then revisit them in Part III, discussing their relevance in light of current technology.

\section{Cost}

Perhaps the dominant concern underlying limited publication plans is the cost associated with expanded publication. The term "publication" has historically referred to the printed reproduction of a case in a bound volume. Purchasing these bound volumes, from either a private or a government-sponsored publisher, is expensive. ${ }^{19}$ Moreover, it costs money to maintain a collection of these volumes, for the more volumes that are published and purchased, the larger the physical facility required in which to store them. This is why critics complain about miles of bookshelves stretching away "into the dim distance."20

In addition to its effect on the cost of buying and storing law reporters, expanded publication increases research costs. More time is required to sort through more cases. The legal researcher must spend

17. Reports of the Proceedings of the Judicial Conference of the United States 12 (1974).

18. Id.

19. For instance, a bound volume set of West's Federal Reporter, F.2d and F.3d series (1,070 total volumes), costs $\$ 22,360$. Telephone Interview with West sales representative (April 3, 1996).

20. See, e.g., supra text accompanying note 9; Eugene M. Prince, Law Books, Unlimited, 48 A.B.A. J. 134 (1962) (providing an example that if the Los Angeles County Law Library had placed its collection in one row it would have spanned 11 miles). 
additional time searching to find the relevant precedent and to distinguish the irrelevant. Because time is money in legal practice, the cost of research increases with the increase in case law.

Driving this cost issue is an underlying concern for fairness. This concern is not simply about judges and lawyers incurring greater costs to update their libraries. Rather, the concern is that these higher costs will ultimately be passed on to the consumer. If it becomes more expensive to research the law, those with greater resources will be increasingly favored and the access-to-justice inequities that currently exist between the rich and the poor will be further magnified.1

\section{Judicial Efficiency}

The federal court system faces an enormous caseload.22 One means of helping to alleviate the backlog of cases is to limit publication of appellate opinions. ${ }^{23}$ Appellate judges spend a great deal of time writing opinions. ${ }^{24}$ The judicial efficiency argument urges that if opinions are selectively published, judges can spend less time writing opinions and more time deciding a greater number of cases.

The judicial efficiency argument is premised on the belief that judges can predetermine which cases are so unimportant that publication is unnecessary. To understand which opinions are worthy of publication and, therefore, efficient to publish, it is necessary to first examine the primary functions served by appellate opinions.

Courts, through their opinions, serve two paramount social functions: resolving disputes and enriching the supply of legal rules. ${ }^{25}$ These two functions have been termed the dispute-settling and the law-

21. For a discussion of additional cost concerns, see William L. Reynolds \& William M. Richman, The Non-Precedential Precedent-Limited Publication and No-Citation Rules in the United States Courts of Appeals, 78 Colum. L. REv, 1167, 1188-89 (1978).

22. For instance, in 1994 there were 48,815 cases commenced in the United States Courts of Appeals. Statistical ABSTRACT, supra note 1. In 1994, the median amount of time rcquired to dispose of a case (from filing notice of appeal to final disposition) in the federal appellate system was 10.5 months. Id.

23. Some commentators have urged much more fundamental changes to our judicial structure as a means of dealing with the challenges posed by the federal court system's enormous caseload. See e.g., RichaRd A. POSNer, The Federal Courts: CRISIS AND REForM viii, 120-27 (1985); see also Paul D. Carrington, Crowded Dockets and the Courts of Appeals: The Threat to the Function of Review and the National Law, 82 HARv. L. REv. 542 (1969) (proposing methods of restructuring the federal appellate system).

24. In 1978, Reynolds \& Richman noted that "[1]ittle in the way of empirical observation of a judge's use of his time is available. A study of seven Third Circuit judges found that $48 \%$ of 'case time' (30\% of total 'judge time) was spent on opinion writing." Reynolds \& Richman, supra note 21, at 1183 n.95 (quoting 2 Advisory COUNCil FOR APPELlate JUSTICE, APPELlate JUSTICE: 197549 (1975)). Although I do not have more recent estimates, it seems safe to presume that, given the increasing caseload of the federal courts, judges today spend a similar (if not greater) percentage of their time writing opinions.

25. See Melvin Aron Eisenberg, The Nature of the Common law 4 (1988). 
making functions of courts. ${ }^{26}$ The dispute-settling function of a judicial decision is to decide the case, putting an end to the immediate dispute. ${ }^{27}$ The opinion explains to the parties the result of the case. The lawmaking function of a judicial decision is "to establish the law itself, to determine what the content of the law shall be. This is the function of common law precedent, and of the rule of stare decisis." ${ }^{28}$ Pursuant to this function, courts not only establish the law, but also criticize legislation and legal doctrine, and comment upon social and legal problems. ${ }^{29}$

Selective publication of opinions is justified as follows: The public at large receives benefits only from those opinions that serve the lawmaking function. ${ }^{30}$ Those appellate opinions that serve only the dispute-settling function benefit only the trial court and the parties to the case, and have no value to the general population. Accordingly, the ends of judicial efficiency are served by limiting opinion publication to those opinions which establish law or have precedential value. These are the only opinions that are worthy to be preserved for future generations on the printed page. ${ }^{31}$ Consequently, it is only upon these opinions that judges should spend time polishing their prose and checking for proper citation. ${ }^{32}$

\section{B. Historic Rationale for Prohibiting Citation to Unpublished Opinions}

Once the decision has been made to limit publication, a second question arises: Should citation to unpublished opinions be allowed? The historical justification for prohibiting citation can be subdivided into two related arguments: allowing citation would (1) frustrate the purposes of selective publication and (2) promote unfairness. ${ }^{33}$

The first argument against citation to unpublished opinions is that if it is allowed, the purposes of selective publication-reduced cost and increased judicial efficiency - will be frustrated. It is argued that if citation to unpublished decisions is permitted, a market for these opinions

26. See Reynolds \& Richman, supra note 21, at 1182.

27. See Robert A. Leflar, Sources of Judge-Made Law, 24 OKLA. L. Rev. 319, 319 (1971).

28. Id.

29. See Reynolds \& Richman, supra note 21, at 1182-83.

30. See id. at 1183.

31. See KATSH, supra note 4, at 5 (describing " $[t]$ he strength, and at times the weakness, of the book").

32. See Comm. on the Use of Appellate Court Energies, advisory Council for Appellate Justice, fJC Research Series No. 73-2, Standards for Publication of Judiclal OpInions 5 (1973). [hereinafter Standards for Publication]; see also Posner, supra note 23, at 124 (commenting that "unpublished opinions are less carefully prepared because the judges put less time into them, not because they are lazy but because they are trying to use their limited time as productively as possible").

33. See Reynolds \& Richman, supra note 21, at 1185. 
will develop. ${ }^{34}$ Legal researchers will feel compelled to search these opinions for relevant case law. Practitioners and law libraries will then purchase and index these opinions in response to the developing market. Accordingly, substantial cost savings will be lost. ${ }^{35}$

Judicial efficiency may also suffer since, if citation is allowed, judges may feel obliged to spend more time writing these opinions. For example, an opinion written only for the parties to the case can exclude background and factual information, with which it can be presumed the parties are already familiar. If, on the other hand, a case may be cited by future litigants, this familiarity may not be taken for granted. Therefore, judicial energy may be spent reciting such background information.

The second argument against allowing citation to unpublished opinions is that to do so would be unfair. Unpublished opinions are more difficult to access because they are not published in the bound volumes and are not located in the traditional digests available to the legal researcher. The combination of this restricted access with freely allowed citation would benefit attorneys with greater time and resources.

Another fairness concern is that those who regularly practice in a particular court will benefit. ${ }^{36}$ Recall that opinions are not published because they are considered to have value only to the particular litigants in the case and not to the public at large. ${ }^{37}$ Because unpublished opinions are distributed to the parties to the case, the concern is that repeat litigants, such as government attorneys, may maintain a file of these opinions that would be unavailable to future opponents who may litigate similar issues. ${ }^{38}$ Citation should therefore be prohibited so that these

34. See, e.g., Commission on Revision of the Federal Court appellate System, Structure and Internal Procedures: Recommendations for Change 51 (1975); 1 Hearing.s Before the Comm'n on Revision of the Federal Court Appellate System 452 (2d phase 1974-75) [hereinafter Hearings] (testimony of Edward H. Hickey, president of the Bar Association of the Seventh Circuit).

35. See Reynolds \& Richman, supra note 21, at 1186-87.

36. See, e.g., StandardS FOR PUblication, supra note 32, at 18; Stienstra, supra note 16, at 3 (identifying the U.S. Attomey as one example of a frequent litigant who may benefit if citation to unpublished opinions is allowed); Joiner, supra note 11, at 199; Reynolds \& Richman, supra note 21, at 1179 (explaining that some circuits allow parties to request that opinions be published and that habitual litigants, such as the U.S. Attomey, have a greater incentive to make such a request so that they may rely on the opinion in a later case); Lauren K. Robel, The Myth of the Disposable Opinion: Unpublished Opinions and Government Litigants in the United Stutes Courts of Appeals, 87 MicH. L REv. 940, 958-59 (1989).

37. See Leflar, supra note 27 and accompanying text.

38. See Robel, supra note 36, at 957 (noting that the Office of Immigration Litigation-an office within the Department of Justice-stated that it maintains an index of unpublished sources). 
attorneys do not benefit at the expense of smaller or less well-funded litigants. ${ }^{39}$

These historic rationales for the limited publication/no-citation plans warrant re-examination in light of current technology. Increased access to both published and unpublished legal opinions through the computer brings to the forefront new concerns while relegating some old concerns to the past. Further, as technology alters the available body of law, it exacerbates some of the practical problems with current limited publication/no-citation plans. I will revisit the historic rationale in light of these changes below.

II

The Problem: Behavior of Judges and Litigants Demonstrates That UnPublished Does Not Mean Unimportant

Selective publication is intended to serve as a sorting device, separating the wheat from the chaff. Opinions that have general precedential value or other public significance are separated from those that do not. If the plans function without error, then examining technology's effect on the justifications for selective publication would be superfluous. If, on the other hand, the selection mechanism works imperfectly, then the plans are open to question. Therefore, before embarking on an examination of the effects technological advancements have had on the rationale for limiting publication, I first seek to demonstrate that a problem does, in fact, exist: many unpublished opinions do contain legal analyses that are important to future litigants and to the public at large.

Limited publication plans generally seek to publish only cases of general precedential value. ${ }^{40}$ Accordingly, it may be widely assumed that unpublished decisions are of little value because they are largely frivolous cases or little more than a mechanical application of existing law to a set of facts. ${ }^{41}$ In many cases this assumption is undoubtedly true. ${ }^{42}$ In many other instances, however, this is not the case. As Judge

39. Compare StIEnSTRA, supra note 16 , at 3 (noting that prohibiting citation may lead to unacknowledged use of unpublished decisions which would exacerbate the fairness problem), with Reynolds \& Richman, supra note 21, at 1195-99 (arguing that unequal access is not unfair).

40. This is the general premise of the limited publication plans. An example of specific criteria for a publication plan can be found in the Fourth Circuit, which calls for publication of an opinion if: "(i) It establishes, alters, modifies, clarifies, or explains a rule of law within this Circuit; or (ii) It involves a legal issue of continuing public interest; or (iii) lt criticizes existing law; or (iv) It contains a historical review of a legal rule that is not duplicative; or $(v)$ It resolves a confiict between panels of this Court, or creates a conflict with a decision in another circuit." 4TH CIR. R. 36(a).

41. See, e.g., Songer, supra note 12, at 307.

42. An example of such a case was pointed out by Judge Nichols of the Federal Circuit who stated that "forests [should not] be destroyed to disseminate and perpetuate statements such as this, from a recent unpublished decision: 'Although petitioner seems unaware of it, we do not have 
Posner has noted: "[M]any appeals that formerly would have been decided with a full opinion ... are now decided with an unpublished opinion. These are not frivolous appeals; one-line treatment ["affirmed," for example] would be inappropriate. They call for an opinion and they get it, but it is not published." ${ }^{.43}$ If what Judge Posner says is true, then it cannot fairly be assumed that unpublished opinions are, by definition, unimportant. ${ }^{44}$

We need not simply take Judge Posner at his word. A survey of court behavior readily refutes the assumption that unpublished opinions are without value to future litigants. One illustration of this fact is that unpublished opinions are sometimes accompanied by a dissent. ${ }^{45}$ If two judges, both ruling from the same trial court record, disagree about the correct application of the law, it would seem quite doubtful that the opinion was such a mechanical application of law that it is of no value to future litigants. ${ }^{46}$ Recognizing this contradiction, three circuits have specifically provided that an opinion accompanied by a dissent should be published in some circumstances. ${ }^{47}$ Certainly, parties disputing an issue similar to that previously decided would benefit from the divided reasoning of the prior judicial panel. The court in the subsequent case would presumably also benefit by knowing the reasons for the split of opinion in the previous case.

A perverse twist on the mechanics of the publication decision further illustrates that some unpublished opinions are incleed important. In the Federal Circuit, opinions accompanied by a dissent are required to be published only if the dissenting judge so insists. Judge Philip Nichols, Jr. of the Federal Circuit candidly admitted that, if dissenting, he would never insist on publication. His rationale: Better to have the opinion banished from existence than be bound by what he considers

jurisdiction to review the initial decision of February 5, 1985, which becaune final March 12, 1985, because he failed to appeal within the period set by statute, 5 U.S.C. $\$ 7703(b)(1)$, and that portion of the appeal must be dismissed." $"$ Philip Nichols, Jr., Introduction, Selective Publication of Opinious: One Judge's View, 35 AM. U. L. REv. 909,920 (1986).

43. POSNER, supra note 23, at 122.

44. When I speak here of the importance or unimportance of unpublished decisions, I refer to their importance in the law-making sense. The decision to limit publication is based on the judgment that these opinions lack value to future litigants. See supra text accompanying notes 22-33. I thus use the term (un)importance to refer to a decision's value to the court or litigants in a future case.

45. See, e.g., STIENSTRA, supra note 16, at 34-45.

46. But see Nichols, supra note 42 , at 925 (arguing that a "dissent may be based on something other than a difference of opinion about the law, for example, whether a fact finding has the support of substantial evidence"). However, Judge Nichols concedes that a dissent to an unpublished opinion may well be over a point of law when he admits that, if dissenting, he would never insist on publication: "it would result in making the decision I objected to precedential instead of nonprecedential." Id.

47. See 5TH Cir. R. 47.5.1; 6TH CiR. R. 24(a)(iv); 9TH CIR. R. 36-2(g). 
bad precedent in the future. ${ }^{48}$ Judge Nichols also notes that in circuits which require the publication of opinions accompanied by a dissent, ${ }^{49}$ an even more disingenuous practice likely occurs. In these circuits, he believes, "tying up the question of dissenting with publication may work adversely on the dissenter, constraining him not to dissent ...."50 Apparently this practice is more than mere speculation. A 1991 article attributed one scholar as saying that law clerks had told her "that judges sometimes would agree not to dissent if an opinion remained unpublished." ${ }^{\text {"SI }}$ It can fairly be assumed that these agreements also were made to limit disagreeable precedent. Paradoxically, this practice demonstrates the importance of rendering a decision "unimportant" (or, more correctly stated, the importance of rendering a decision nonprecedential). As I will later argue, suppressing precedent in this fashion is directly at odds with the fundamental nature of an evolving common law. ${ }^{52}$

California's experience with unpublished opinions from the federal courts provides another example of the future value these opinions sometimes serve. In California, state courts of appeal have disagreed over the meaning of Rule 977, which prohibits citation to "[a]n opinion that is not ordered published." 53 The rule does not specify whether it applies only to unpublished opinions of state appellate courts, or whether unpublished opinions of federal courts are also within its intended scope. ${ }^{54}$ Because of this ambiguity, some state appellate courts have cited and relied on unpublished federal opinions while others have held these opinions beyond the cognizance of the state courts..$^{55}$ The

48. Nichols, supra note 42 , at $924-25$.

49. See supra note 47 and accompanying text.

50. Nichols, supra note 42 , at 925 .

51. Paul Marcotte, Unpublished but Influential: With Technology, Opinions Not in the Law Books Can Be Misused, Critics Charge, A.B.A. J., Jan. 1991, at 26, 28.

52. See infra text accompanying note 130 .

53. CAL. R. CT. 977; see infra note 55 .

54. Effective January 1, 1983, the California Supreme Court and the Judicial Council amended Rule 977 of the California Rules of Court to provide, with certain exceptions, that "[a]n opinion that is not ordered published shall not be cited or relied on by a court or a party in any other action or proceeding ...." Supreme Court of California, Proposed Amendment of Rule 977 of the CALIfornia Rules of Court, Request for Public Comment [hereinafter Supreme Court of CALIFORNIA] (memorandum requesting comments on proposed changes to Rule 977 be sent to the court clerk by January 1996). Prior to the amendment the rule had specified that the prohibition applied only to "opinion[s] of a [state] Court of Appeal or of an appellate department of a superior court" that had not been ordered published. Id.

55. One year after amended Rule 977 took effect, one of the state courts of appeal cited a federal district court opinion that was not published in the bound Federal Supplement, and was only available on-line: Appalachian Insurance Company v. Superior Court, 208 Cal. Rptr. 627, 633 (Ct. App. 1984) (citing Gould, lnc. v. Nat'l Union Fire lns. Co., LEXIS 82-C-3154 (N.D. 1ll. Nov. 17, 1983)).

By contrast, in 1993 another court of appeal refused to recognize any federal district court decisions that "have not been officially published and can only be 'accessed' by means of a 
disagreement has generated enough controversy to motivate the California Supreme Court to recently request public comment on proposed amendments to Rule 977.56 Regardless of the ultimate resolution of this dispute, the fact that unpublished opinions from the federal courts have generated such controversy demonstrates the lawmaking function some of these opinions serve.

Additional evidence that unpublished opinions can be important to the resolution of future cases can be found in the confused practice of the Fifth Circuit. The Fifth Circuit limits case publication by requiring that publishable judicial opinions meet a defined set of criteria. These Fifth Circuit criteria are designed to publish "every opinion believed to have precedential value." 57

However, the judges sometimes miss the mark. In Hodges v. Delta Airlines, Inc. ${ }^{58}$ the court stated that, contrary to its belief that the federal Airline Deregulation Act of 1978 should not have preemptive effect, it was bound by an earlier, unpublished case to hold that the federal act preempted a tort suit for personal injuries caused by unsafe in-flight conditions. The court was bound in this case because in the Fifth Circuit, "[u]npublished opinions . . . are precedent."

Similarly, in Peters $v$. United States, ${ }^{(0)}$ the court again relied on an unpublished opinion as precedent. However, not only did the court rely on an unpublished opinion in Peters, but it also originally intended that

computerized legal research service." ACL Technologies, Inc. v. Northbrook Property \& Cas. Ins. Co., 22 Cal. Rptr. 2d 206, 212 n.34 (Ct. App. 1993). The court stated that it believed "such unpublished federal slip opinions are beyond the cognizance of Califomia courts. The California rule against citation to unpublished opinions makes no differentiation between state and federal cases." Id. The following year another court of appeal opinion disregarded this view by citing and quoting from a federal district court decision that had not been published in the Federal Supplement, but rather was available only on-line: Norman L. Krug Real Estate Investors, Inc. v. Praszker, 28 Cal. Rptr. 2d 498, 508 n.5 (App. Ct. 1994) (Kline, P.J., concurring) (citing Washington Metro. Transit Auth. v. One Parcel of Land in Prince George's County, 1993 WL 524783 (D. Md. Nov. 23, 1993)).

A few months later, another court of appeal once again took the contrary view when it refused to recognize a federal district court case that was unavailable in the printed Federal Supplement. This case presented a slightly different twist; it was only available in the topical reporter American Maritime Cases. In declining to take cognizance of such a case, the court reasoned that "cases which have not been officially published, though accessible through computerized data bases or specialty digests such as American Maritime Cases, may neither "be cited [11]or relied on by a court or a party ...."' Lewinter v. Genmar Industries, lnc., 32 Cal. Rptr. 2d 305, 308 n.1 (1994) (quoting CAL. R. CT. 977(a)).

56. See Supreme Court of California, supra note 54.

57. STH CIR. R. 47.5.3.

58. 4 F.3d 350, 355 (5th Cir. 1993), rev'd and remanded, 44 F.3d 334 (5th Cir. 1995) (en banc).

59. 5TH CIR. R. 47.5.3. It should be noted that the Fifth Circuit adopted a new rule effective January 1, 1996. According to this new rule, unpublished opinions issued on or after January 1, 1996 are no longer precedent but only persuasive. The new rule also allows citation to post-1995 unpublished opinions. See 5TH CIR. R. 47.5.4. However, Rule 47.5.3 still applies to pre-1996 unpublished opinions. See infra note 134 for the language of the two Fifth Circuit rules.

60. 9 F.3d 344, 346 (5th Cir. 1993). 
Peters itself be an unpublished opinion. ${ }^{61}$ Had the court not acquiesced to the publication request of the Assistant United States Attorney on the case, the court may have fashioned an "underground stream of precedent-unpublished opinions relying on other unpublished opinions."

Although these experiences are anecdotal, they do refute a fundamental premise upon which limited publication plans are built. If these opinions do indeed contain analysis important to the resolution of future cases, then they are too important to allow judicial efficiency concerns to take precedence over the value of common law precedent. To quote one commentator: "[with non-publication] [s]tare decisis is twice diminished. First, the decision itself is freed from the responsibility to reason within full view. Second, an increment of precedent is rendered unusable." ${ }^{63}$

These examples do not represent isolated experiences. A number of scholars have demonstrated that in many cases unpublished decisions are in fact precedential or do have future importance to legal decision makers. These studies range from the anecdotal to the empirical. ${ }^{64}$ For instance, many scholars have examined sample groups of unpublished opinions and have noted numerous instances of unpublished opinions that in fact did make law. ${ }^{65}$ These studies and other anecdotal evidence readily demonstrate that many unpublished opinions do in fact turn out to contain analyses that are important to the resolution of future cases.

61. See James W. Paulsen \& Gregory S. Coleman, Civil Procedure, 26 TEX. TECH L. REv. 397, 440-41 (1995).

62. Id. at 441 .

63. Thomas E Baker, Rationing Justice on Appeal: The Problems of the U.S. COURTS OF APPEAL 130 (1994).

64. See, e.g., Reynolds \& Richman, supra note 21, at 1192-93 (citing examples of unpublished opinions containing precedential analyses).

65. See, e.g., Pamela Foa, A Snake in the Path of Law: The Seventh Circuit's Non-Publication Rule, 39 U. PITT. L. REv. 309, 315-38 (1977) (evaluating all unpublished orders issued by the Seventh Circuit over a six month period and concluding that "cases are being decided which (if given precedential effect would) create new law"); James N. Gardner, Ninth Circuit's Unpublished Opinions: Denial of Equal Justice?, 61 A.B.A. J. 1224, 1226 (1975) (noting Ninth Circuit unpublished cases that, "if published, would set precedent"); Reynolds \& Richman, supra note 16, at 584-586, 606-611 (noting that the results of a sample of the published and unpublished opinions of the federal courts of appeals during the 1978-79 Reporting Year revealed a number of instances of cases that ought to have been published but were not, including cases which resolved novel issues of state and federal law, as well as "decisions suggesting that statutes, agencies, or the courts themselves are not performing up to par"); Lauren K. Robel, Unpublished Opinions in the Court of Appeals for the Ninth Circuit (1988) (unpublished report to the United States Court of Appeals for the Ninth Circuit, cited in Robel, supra note 36, at 946 n.33) (studying all Ninth Circuit opinions issued during a one year period, classifying the unpublished opinions by subject matter, and analyzing their information value); Songer, supra note 12, at 313 (noting that "[a] significant number of the unpublished decisions of the courts of appeals appear to involve cases which are non-routine [and] sometimes politically significant"). 
III

\section{A Critique of Historic Rationale in Light of CurRent TechNology}

In 1964, when limited publication was first officially proposed by the Judicial Conference of the United States, ${ }^{66}$ computer-assisted legal research was little more than theory. ${ }^{67} \mathrm{~A}$ few years later, when the federal circuits devised and implemented their limited publication plans in the early 1970 s, $^{68}$ computer-assisted legal research was an idea whose time would come, but as a commercially-available product it was only in its infancy. ${ }^{69}$ Lexis, the first commercially-available computer-assisted legal research service, was introduced to the market in April 1973. ${ }^{70} \mathrm{By}$ the fall of 1973, a handful of law firms had begun using Lexis to perform legal research. ${ }^{71}$ In 1975 , Lexis' first competitor entered the market when a primitive Westlaw product was introduced. ${ }^{72}$ Computerassisted legal research was thus only beginning to proliferate when the publication plans were adopted.

Accordingly, the arguments in favor of the limited publication plans were necessarily premised on legal storage and research as it then existed-on the printed page. Questions of cost, fairness, access and efficiency were all fundamentally linked to this paper-based publishing regime. Reevaluation of the premises for selective publication is thus relevant in view of the widespread availability of digital information today.

Advancements in information communication have revolutionized legal research and access to legal information. Legal information is no longer available exclusively in print and the researcher is now no longer constrained by the limitations of the printed page. Instead, this information can be stored, indexed and retrieved digitally. Because it is an institution built on the creation, storage, processing, and communication of information, "law cannot remain unaffected by large-scale changes in the communication of information."73 Given this premise, I seek to critically examine the limited publication rules-rules that are tied to an older, less powerful and less interactive means of communication-and

66. See 1964 REPORT, supra note 14.

67. See William G. Harrington, A Brief History of Computer-Assisted Legal Reseurch, 77 LAW LIBR. J. 543, 543-53 (1985) (noting that prior to the first experiments in 1965, computer-assisted legal research was little more than "[t]alk, talk, talk").

68. See supra text accompanying note 16.

69. See Harrington, supra note 67 , at $543-45$ (chronicling the history of computer-assisted research).

70. See id. at 553.

71. See id.

72. See id.

73. M. Ethan Katsh, The Electronic Media and the Transformation of Law 5-6 (1989); see also KATSH, supra note 4 and accompanying text. 
to challenge the applicability of these rules to the changed circumstances of today's digital world.

\section{A. The Selective Publication Argument Revisited}

Digitally available case law has affected the rationale for limiting opinion publication in several ways. Most dramatically affected have been the direct costs of performing legal research. The impact of advanced communication technology on the price of legal information, however, is complex ${ }^{74}$ and I do not endeavor here to sort out the effect technology has had generally on price. ${ }^{75}$ Instead, I will focus on the

74. A complicating factor, which is beyond the scope of this Comment, is the effect on the cost of legal research of current rules regarding citation to an "official" reporter. In the federal system, the official reporter for appellate opinions is West's Federal Reporter. Accordingly, all pincites must refer to the page number from the West-published book. The problem to competing publishers is that West maintains that the internal pagination scheme of its reporters is copyrighted-a claim that was upheld by the Eighth Circuit. West Publishing Co. v. Mead Data Cent., Inc., 616 F. Supp. 1571, 1579 (D. Minn. 1985) (granting preliminary injunction enjoining Mead from including on LEXIS "star pagination" to West reporters), affd, 799 F.2d 1219 (8th Cir. 1986). Accordingly, competing publishers, who may digitally publish cases on CD-ROM or on the Internet, are disadvantaged. To include, without license from West, "star pagination" denoting the pagination of the West-published official reporters would constitute infringement. See id., 616 F. Supp. at 1579-80. Without official pagination, these case law products are not viable market competitors since researchers are unable to obtain the official page numbers required by the courts. See Gary Wolf, Who Owns the Law?, WIRED, May 1994, at 98, 98 (noting that "[a]ny publisher is free to compile collections of federal decisions, but without citable page numbers these collections are little more than worthless"). Wouldbe competitors thus claim to be prevented from entering or effectively competing in the market. See Robert Berring, On Not Throwing Out the Baby: Planning the Future of Legal Information, 83 CALIF. L. REv. 615, 630 (1995); Richard C. Reuben, Online Legal Publishing Gets DOJ Review, A.B.A. J., Dec. 1994, at 38, 38. The complaints have been pervasive enough to prompt the Antitrust Division of the United States Department of Justice to investigate whether there exist barriers to entry into the computer-assisted legal research market. See id. Because of West's monopoly power in controlling case law citation and the resulting competitive barriers, the price of on-line legal research may be artificially high. See, e.g., id. (quoting Attorney General Janet Reno's statement that the department's actions stem from "considerable correspondence from members of the legal community [who are] concerued about the high cost of electronic access to judicial opinions and the present proprietary system most often used to cite cases"); Susan Hansen, Fending Off the Future, AM. LAw., Sept. 1994, at 74,76 . In response, some have proposed that courts adopt vendor-neutral citation systems. See Berring, supra, at 630. In a typical vendor-neutral plan, each paragraph in an opinion would be numbered. See id. Parties could then pincite to the appropriate paragraph number-a system that would eliminate the need for page numbers, which are an artificial construct of the printing process. Legal researchers would then no longer be compelled to locate the information in any particular format. See id.

Critics have raised a number of concerns about these vendor-neutral citation schemes. See Berring, supra, at 629-34. The most compelling of these concerns is the effect vendor-neutral citation would have on the reliability of legal information. The main purpose of citation is to allow a reader to consult the cited source to verify the accuracy of the information presented. See id. at 632 . If lawyers were precluded from disclosing the source of their information, it would be impossible to verify where the citing party really saw the information. See id.

75. Some have argued that technological advances may have actually increased the cost of legal research due to an increased standard of care. See Daniel P. Dabney, The Curse of Thamus: An Analysis of Full-Text Legal Document Retrieval, 78 LAW LIBR. J. 5, 38-39 (1986) (asking whether it 
effects of digitally-available case law upon the rationale for the nopublication/no-citation plans.

\section{Storage Costs}

The most obvious effect technological advancements have had on cost involves the cost of physically storing information. Today, the practitioner's library need not have space for miles of bookshelves. One CD-ROM disc, which is wafer thin and a mere five inches in diameter, can store as much information as that contained in 30 to 60 printed volumes. ${ }^{76}$ The information contained in thousands of volumes can now be stored in a file cabinet. The cost savings from the resulting need for less physical space can be dramatic-especially in the highrent office space in which many law firms are located. ${ }^{77}$ Moreover, the current cost of case law on CD-ROM is far less than that of the printed case reporters. ${ }^{78}$ The physical storage cost savings can be realized while simultaneously saving money by purchasing the information in digital, rather than printed, form. ${ }^{79}$

While public law libraries will likely continue to purchase the books rather than the compact discs, this need not be the case. One can imagine a library of the future where patrons sit at computer terminals searching through compact discs or on-line information rather than browsing through bookshelves. ${ }^{80}$ The cost savings resulting from storing legal information in digital, rather than print, format would be substantial. However, even if we assume that the library of the future will continue to look like the library from the past and retain books, unpub-

violates an attorney's duty of care to fail to use computer-assisted research to obtain the most current case law).

76. See Technology Resource Comm., Proposed Citation System for Wisconsin: Report TO THE Wisconsin State Bar BoARd of Governors 6-7 (June 22, 1994).

77. For instance, in San Francisco's financial district, the going rate for office space is approximately $\$ 36$ per square foot per year. Telephone Interview with David Becker, San Francisco commercial realtor with Ritchie \& Ritchie Corp. (Oct. 16, 1996).

78. As an example, a 21 disc CD-ROM set comprising all the cases published in West's Federal Reporter F.2d and F.3d series costs \$7,000. Telephone Interview with West sales representative (April 3, 1996). This same set of bound volumes costs more than $\$ 22,000$. See supra note 19. In California, a two-disc set from AccessLaw containing 685 volumes of material including second, third, and fourth Series California Cases back to 1934, as well as California Codes, the Rules of Court, and the California Constitution costs only $\$ 799$. Moreover, it costs only $\$ 89$ per quarter for a subscription update. See Susan E. Davis, Tune In, Turn On, Log Off: Good Legal Research Doesn't Have to Be Expensive, CAL. LAw., April 1996, at 47. By comparison, the bound volumes of just the California Code cost about $\$ 2,000$. See id. at 55 .

79. Additionally, there are initial costs to purchase the equipment to read and search CD-ROM discs. In 1994, the cost of a CD-ROM drive was estimated in the $\$ 150-400$ range and the cost of a common search engine was estimated at between $\$ 100$ and $\$ 300$. See Technology Resource Comm., supra note 76 , at 7-8.

80. However, it may be that, due to underfunding and public unfamiliarity, this library of the future is still in the distant future. See Berring, supra note 74, at 626-27. 
lished opinions will not significantly add to the book collection because, for the most part, they are only published electronically. ${ }^{81}$ Current technology allows an opinion to be ordered "not published" but nevertheless to be widely disseminated in digital format. Thus, forests do not have to be destroyed ${ }^{82}$ and library bookshelf space does not have to increase in order for parties with digital capabilities to have access to, and use of, unpublished opinions.

\section{Research Costs}

Although more case law seems inevitably to lead to increased costs, technology has probably mitigated this effect. The decision to selectively publish was primarily driven by a generalized fear of the exponential growth in case law. ${ }^{83}$ This concern was particularly keen given the inherent limitations of the paper-based publishing regime that dominated at the time the publication plans were introduced. Who can doubt that the prospect of manually negotiating millions of cases in order to find the relevant few was indeed overwhelming? ? $^{84}$

As the availability of computer-assisted legal research has become more widespread, the use of manual research has declined. A researcher today can sift instantly through the vast sea of case law, retrieving or Shepardizing a relevant case in a matter of seconds. Accordingly, the need to search through a greater number of cases is at least partially offset by the aid of more efficient computer-assisted research techniques. Computerization is not a panacea, however. For all of its power and speed, it brings with it new costs and unique problems. ${ }^{85}$

One such problem, particularly relevant to the electronic dissemination of unpublished opinions, is that as databases get larger the ability to efficiently locate relevant documents diminishes. ${ }^{86}$ This phenomenon occurs due to the inexact nature of free-text searching. With free-text searching, the researcher searches for words that are deemed relevant to

81. For instance, although unpublished opinions are, for the most part, made available by the different circuits, these opinions are not published in the bound volumes. Though some are published in print form in specialty reporters such as BNA's Labor Relations Reference Manual, most are available to the public only in digital format. See Robel, supra note 36, at $961 \mathrm{n} .96$.

82. See Nichols, supra note 42.

83. See supra text accompanying notes 5-16.

84. See Joiner, supra note 11 , at 195 (proclaiming that "there are limits on the capacity of judges and lawyers to produce, research, and assimilate the sheer mass of judicial opinions"). Joiner estimated that the number of published decisions in 1972 totaled close to three million. Id.

85. Others have described in great detail some of the unique problems of computer-assisted legal research. See Dabney, supra note 75; Robert C. Berring, Full-Text Databases and Legal Research: Backing into the Future, 1 HIGH TECH. L.J. 27 (1986); see also supra notes 74-75.

86. For a detailed discussion of this phenomenon, see generally Dabney, supra note 75; Berring, supra note 85 . 
the problem at hand. ${ }^{87}$ The problem with this approach is that there is an imperfect correspondence between words and ideas. ${ }^{88}$

[M] uch of the meaning of natural language texts is contained in complex relationships between words rather than in the individual words themselves. Simple word recognition of the kind done by LEXIS and WESTLAW cannot discern the meaning of complex expressions because the relationships between words in natural text are much more subtle than the connectors that may be used to join terms in [computer-assisted] searches. ${ }^{89}$

Due to this low correlation between words and ideas, a free-text search retrieves both relevant and irrelevant documents. In small databases, this is not a problem because the researcher can easily scan the documents to weed out the irrelevant. However, in very large databases winnowing the irrelevant can become impractical..$^{90}$ In order to increase the precision of the search (retrieve fewer irrelevant documents), it thus becomes necessary to add more detail to the search request. This tactic does succeed in retrieving fewer docuinents; the problem, however, is that the search will also exclude relevant material. ${ }^{91}$ Accordingly, the larger the collection of documents in a database, the poorer the performance of the computer-assisted search..$^{92}$ If unpublished opinions are added to digital databases, their inclnsion will exacerbate this problem.

This is not a fatal flaw, however. As one prominent law librarian points out, failure to retrieve all the relevant cases in one workable search does not make the search nseless. ${ }^{93}$ In reality, the researcher need only retrieve a few relevant cases. The researcher is then tapped into the larger legal discussion of the issue at hand. ${ }^{94}$ By finding even "one good case," found by locating the authorities cited in the cases retrieved. The computer's power facilitates this process by allowing a researcher, with only a few keystrokes, to instantly locate the relevant text of a cited authority. ${ }^{96}$ The overall effect of the digital revolution-even when consider-

87. See Berring, supra note 85 , at 41 .

88. See Dabney, supra note 75 , at 18.

89. See id. at 19.

90. See Berring, supra note 85, at 43-50; Dabney, supra note 75, at 21-30.

91. See Berring, supra note 85, at 49-50; Dabney, supra note 75, at 21-26.

92. See Dabney, supra note 75 , at 21.

93. See id. at 36-37.

94. See Robert C. Berring, Finding the Law 306 (10th ed. 1995) (noting that "[e]very research tool is part of a larger research universe").

95. Id. at 100-01 (asserting that "[h]alf the battle of legal research is won by having 'one good case' to serve as a basis for finding other cases and resources").

96. For instance, when Shepardizing on-line, a researcher can jump directly from the Shepard's display for the case being viewed to the text of a citing case. Id. at 77 . 
ing the unique problems it brings-has been to make negotiating lots of law less daunting. The general fear about too much case law, though real, is surely mitigated by the power of advanced communication technology. Thus, increased research costs provide less impetus for limiting publication than they did before computerized research was a reality.

\section{Intellectual Costs}

A final cost of too much published case law that has been discussed in the academic literature is not financial but intellectual. Some commentators argue that if there are too many decisions, there will be too much diversity of opinion. ${ }^{97}$ Accordingly, it will not be possible to distill coherent legal principles from this amorphous mass of case law and confusion and inconsistency will result. ${ }^{98}$ As one author stated:

When the number of printed cases becomes like the number of grains of sand on the beach, a precedent-based case-law system does not work and cannot be made to work....

... The theory of precedent depends, for its ideal operation, on the existence of a comfortable number of precedents, but not too many. ${ }^{99}$

However, the fact that a greater number of opinions is published on a discrete topic of law does not necessarily mean that confusion will result. A string of decisions might ultimately reach the same result, thus solidifying, rather than weakening, the understanding of that topic of law. Indeed, Judge Posner has noted that "[d]espite the vast number of published opinions, most federal circuit judges will confess that a surprising fraction of federal appeals are difficult to decide, not because there are too many precedents but because there are too few on point."100

That many decisions may reinforce prior holdings does not mean that the more recent holdings should not be published. There is value to a litigant in knowing the relevant strength of a legal doctrine. The litigant will benefit by knowing whether a legal principle has been consistently upheld in varied factual circumstances or whether the doctrine has only been challenged a few times. Similarly, the litigant may benefit by knowing whether the legal doctrine has been dormant for a number of years or whether it has withstood challenge more recently. If more recent opinions have not been published because the law was

97. See, e.g., supra note 7 and accompanying text.

98. See, e.g., STANDARDS FOR PUblication, supra note 32, at 6 ("Unlimited proliferation of published opinions constitutes a burden and a threat to a cohesive body of law. ... Common law in the United States could be crushed by its own weight if the rate of publication is not abated.").

99. Grant Gilmore, Legal Realism: Its Cause and Cure, 70 YALE L.J. 1037, 1041 (1961).

100. POSNER, supra note 23, at 123. 
merely applied to new facts, the litigant will be denied the benefit of knowing both the strength and the vintage of the doctrine.

Moreover, if the publication of more cases actually does result in inconsistent rulings, then appellate courts will be forced to clarify the law. Indeed, the implications of the argument that more cases will lead to confusion are striking. Unstated in this hypothesis is the admission that there will indeed be inconsistent rulings but that, to avoid confusion, some of these should simply go unpublished. This notion goes directly against a key argument for limiting publication in the first place-that only those opinions that make law have enough future value to deserve publication. Decisions that are inconsistent with the weight of precedent are, by definition, law-making. These opinions therefore should be published even in the face of fears about an incoherent mass of case law.

Some legal theorists have suggested a modern rationale supporting the public availability of inconsistent legal opinions. Citing the power of current communication technology, Jean Stefancic and Richard Delgado suggest that today's communication technology could pave the way toward faster law reform ${ }^{101}$-arguably a "good" thing. A primary tenet of critical legal theory is that "legal reasoning rarely, if ever, has just 'one right answer.' Instead, there will be multiple interpretations of the available precedent from which judges may choose on the way to resolving the case before them."1112 Advanced technology provides legal researchers with the capacity to perform such tasks as freetext searching. This ability frees the researcher from the constraints of the West paradigm - a system whereby "the information in each of the cases was parsed into a preexisting framework that inevitably tended to suppress subtle changes and to enforce judicial and professional conformity and conservatism." 103 It is thus much easier for the researcher to locate different legal interpretations on emerging points of law. ${ }^{114}$ "[T] he stability of printed texts [has] been challenged by computerization. Precedent will become more manipulable; arguments and lines of cases for opposing viewpoints will be readily available, arguably to the

101. See Jean Stefancic \& Richard Delgado, Outsider Jurisprudence and the Electronic Revolution: Will Technology Help or Hinder the Cause of Law Reform?, 52 OHоO ST. LJ. 847, 855-57 (1991).

102. Id. at 848 .

103. Berring, supra note 85 , at 42 ; see also Berring, supra, note 3 , at $26-27$ (noting that "[a]llowing people to go on-line in free text liberates them from any requirement to fit their thoughts into a pre-existing structure. Individual researchers are able to order legal doctrine as it suits their needs"). See generally Richard Delgado \& Jean Stefancic, Why Do We Tell the Same Stories?: Law Reform, Critical Librarianship, and the Triple Helix Dilemma, 42 STAN. L. REv. 207 (1989) (detailing how traditional pre-coordinated legal indexes constrain novel approaches to the law).

104. See Stefancic \& Delgado, supra note 101, at 854. 
advantage of law reform."105 Since unpublished opinions frequently contain one of the multiple interpretations from which judges may choose, their widespread availability would seem an important ingredient to those pushing for legal reform.

The fear of common law's being crushed by its own weight appears to be voiced in frustration with the overwhelming prospect of searching so much law. At the time these fears were voiced, legal research was done manually and the task of locating relevant law was very time-consuming. In the current era of the computerized search, however, this prospect is much less daunting. Given the power of computergenerated search engines, reports of common law's impending demise appear to have been greatly exaggerated.

\section{B. The No-Citation Rationale Revisited}

Because it is believed that allowing citation to unpublished opinions frustrates the objectives of selective publication (reduced cost and increased judicial efficiency) and promotes unfairness, some circuits forbid citation to unpublished opinions by parties unrelated to the case. ${ }^{106}$ This prohibition relies on the assumption that, by forbidding citation, the courts will preclude the use of unpublished opinions altogether.

The weight of evidence, however, points to the opposite conclusion. Barring citation does not prevent the use of unpublished opinions; it merely alters the character of that use.

Despite the official ban on citation, unpublished opinions are regularly used by litigants in making fundamental litigation decisions. For instance, one survey of the federal government, a frequent litigant, found that federal agencies have used such opinions in making litigation or settlement decisions and in determining whether to appeal or oppose an appeal. ${ }^{107}$

Attorneys and others may also use unpublished opinions as authority in settlement negotiations. For example, in Prudential-LMI Commercial Insurance Co. v. Colleton Enterprises Inc., ${ }^{108}$ a 1992 unpublished decision, the Fourth Circuit court held that a hotel damaged by Hurricane Hugo could not recover "windfall" losses from its insurer

105. Id. at 857 .

106. The circuits restricting citation are the First, Second, Third, Seventh and Ninth. See 1ST CIR. R. 36.2(b)(6); 2ND CIR. R. 0.23; 3RD CIR. I.O.P. 5.8; 7TH CIR. R. 53(2)(iv); 9TH CIR. R. 36-3. However, six circuits allow parties to cite unpublished opinions. See infra note 130 and accompanying text for a discussion of the rules of the circuits that do allow citation.

107. See Robel, supra note 36 , at 956-959.

108. No. 91-1757, 1992 U.S. App. LEXIS 25719 (4th Cir. Oct. 5, 1992). This decision was not published despite the fact that it apparently broke new legal ground (based on its subsequent use by the insurance industry) and was a 2-1 decision that reversed the trial court and was accompanied by a dissent, both indicators that this was not a mechanical application of existing law. 
for being unable to accommodate the influx of repair persons and construction workers who would have booked rooms after the disaster if the hotel had not been damaged. ${ }^{109}$ According to plaintiffs' attorneys, insurance adjusters later used an insurance trade journal article about the decision to deny similar claims after Hurricane Andrew. ${ }^{110}$ Thus, although the Fourth Circuit had banned this opinion's citation, it did not thereby render the decision "unusable."

There are other ways litigants could use unpublished opinions to their advantage. For example, litigants aware of an unpublished opinion's existence can make unacknowledged use of that opinion in their appellate briefs by borrowing successful arguments or by lifting exact language and hypotheticals. Attorneys can also know "which of the court's published opinions were considered relevant by its citations. ... [And] if inconsistency exists between a court's published and unpublished work, it would be of great practical value to know what the court does as well as what it says."111

The court itself may also use unpublished opinions as de facto authority. This may already be happening at the state level. For instance, one member of a Wisconsin state bar committee formed to study the issue of citation to unpublished opinions claims to have heard "stories of lawyers being interrupted when arguing a point in chambers by a judge who blurts out, 'Well, the appellate court ruled the other way in this unpublished opinion I have in my desk drawer." "112 Such a scenario also seems quite possible in the federal circuits, since copies of unpublished opinions are distributed to circuit and district court judges. ${ }^{113}$ Indeed, during the 1974 hearings before the Commission on Revision of the Federal Court Appellate System, Judge Sprecher of the Seventh Circuit advocated the creation of an indexing system for unpublished opinions in order to avoid intra-court conflict: "[W]e are going to have to have some kind of an intra-court index of unpublished opinions, indexed according to the subject matter and so forth. These matters are going to have to be available for the court, even though they cannot be cited by the court or to the court."114 The evidence thus sug-

109. Id. at *1 (4th Cir. Oct. 5, 1992).

110. Richard C. Reuben, New Cites For Sore Eyes: A Second Federal Appeals Court Allows Citation of Unpublished Opinions, A.B.A. J., June 1994, at 22.

111. Reynolds \& Richman, supra note 21 , at 1196.

112. Marcotte, supra note 51, at 26.

113. See e.g., STIENSTRA, supra note 16, at 18-20 (noting that six circuits send unpublished decisions to all appellate judges within the circuit and three circuits send copies to district court judges).

114. Hearings, supra note 34 , at 536. Indexing and using unpublished opinions in this manner would seem to indicate that they were to be used as precedent. By referring to a prior unpublished decision to make sure the case at hand was consistently decided, the judge would appear to be looking to the prior opinion as establishing the law of the circuit on that point. However, later in his 
gests that unpublished opinions are used by litigants and by the courts even where citation has been forbidden.

This use of unpublished opinions in practice calls into question the purposes the no-citation rule is designed to serve. Recall that the first justification for forbidding citation was that permitting citation to unpublished opinions would frustrate the purposes served by limiting publication-reduced cost and increased judicial efficiency. While allowing citation to unpublished opinions may not undermine judicial efficiency, ${ }^{115}$ it clearly does undermine the goal of reduced costs. ${ }^{116}$

Where litigants and courts continue to use unpublished decisions creatively, their inability to cite to them does little to alleviate, and in fact may compound, the cost concerns. As previously discussed, the evidence suggests that many attorneys and judges regularly use unpublished opinions. ${ }^{117}$ Assuming this to be true, court participants spend actual time and resources searching these decisions, and the cost savings intended by not publishing, and by prohibiting citation, are not realized. Costs may actually increase where unpublished opinions are not widely distributed and economies of scale in such tasks as collecting and indexing cannot be achieved. Accordingly, because prohibiting citation does not preclude the use of unpublished opinions in practice, the rationale of reduced cost alone does not justify forbidding citation.

The second major rationale for prohibiting citation to unpublished opinions is that if citation is allowed, well-funded or repeat litigants will have unequal access to these decisions." This is unfair to the "little guy": If he can't find them, he can't cite them and he is thus disadvantaged. However, the fact that litigants nevertheless use these decisions despite prohibited citation raises another problem of fairness: Unacknowledged use of unpublished opinions occurs; therefore well-heeled and institutional litigants benefit from disparate ac-

testimony, the judge both contradicted this assertion and showed confusion as to how unpublished decisions would ultimately be used. See id. at 537-39. Responding to concerns about judicial indexing and use of unpublished decisions not available to the attorneys on the case, Judge Sprecher stated: "I think all I am speaking about is-I am talking about a non-precedential precedent, because I am talking about aids to future production of opinions and not their use as precedents in the stare decisis sense." Id. at 537.

115. The fact that court participants find creative uses for unpublished opinions, despite the ban on citation, probably does not undermine the judicial efficiency goal of selective publication. In the end, a regime where opinions are only selectively published undoubtedly does further the goal of judicial efficiency, because judges will not be required to spend as much time carefully crafting their opinions or reciting background information. This is why I do not believe that selective publication should be scrapped altogether. See Parts IV and V infra.

116. See supra text accompanying notes 19-21.

117. See supra text accompanying notes 107-114.

118. See supra text accompanying notes 35-39. 
cess. ${ }^{119}$ Thus, the core of the fairness argument is access: Unfairness results from unequal access.

The fairness argument must proceed with today's changed communications capabilities in mind. When the limited publication plans were adopted, unpublished opinions were essentially banished from public existence since the bound volumes were the sole source of case law. Technological advances, however, have changed this reality. Today, in jurisdictions that allow for public distribution of unpublished opinions, on-line research services make these decisions widely available. Despite an opinion's unpublished status, public access is possible. Modern courts must therefore account for the electronic availability of unpublished opinions when fashioning their citation rules.

\section{IV}

\section{Fundamental Decisions in Crafting Citation Policy}

In crafting citation policy, courts must make two fundamental decisions: (1) whether to allow the electronic dissemination of all unpublished opinions, and (2) whether to allow citation to those opinions. For the reasons discussed below, courts should allow both electronic dissemination of unpublished opinions and citation to these opinions for their persuasive value.

\section{A. Whether to Allow Electronic Dissemination of Unpublished Opinions}

Three federal circuits currently prohibit the electronic dissemination of unpublished opinions, ${ }^{120}$ attempting thereby to deny access to these opinions to all but the parties to the case. Denying public access to judicial opinions in this fashion may succeed in limiting their use by some litigants. Prohibiting electronic dissemination, however, ignores other important policy considerations.

\section{Access Inequity}

One goal in limiting distribution of unpublished opinions is to deny access to all litigants, thereby leveling the playing field. If neither party to a dispute has access to unpublished opinions, then neither party will be at an advantage. However, as discussed above, repeat or institu-

119. See STIENSTRA, supra note 16 , at 3 .

120. This is the rule in the Third, Fifth, and Eleventh Circuit courts. Telephone Interviews with Brad Baldus, Chief Deputy Clerk, Third Circuit (Oct. 18, 1996); Debbie Taylor, Opinions Clerk, Fith Circuit (Oct. 17, 1996); and Elaine McCombs, Unpublished Opinions Clerk, Elevcnth Circuit (Nov. 12, 1996). In 1994 the Second Circuit also banned electronic dissemination of unpublished opinions. Reuben, supra note 110. However, the Second Circuit recently changed this policy and now places unpublished opinions on the Circuit's electronic bulletin board. Telephone Interview with Kathy Brouwer, Senior Deputy Clerk, Second Circuit (Oct. 17, 1996). 
tional litigants do have access to unpublished opinions in cases to which they were a party. ${ }^{121}$ Indeed, one survey of governmental litigants found that a number of federal government litigation offices circulate copies of unpublished opinions and at least one such office admitted to indexing them. ${ }^{122}$ When public access to these opinions is denied, institutional litigants, who have access by virtue of having been a party to numerous cases, are at a distinct advantage. Prohibiting electronic dissemination may thus actually preserve inequity because litigants who more frequently practice in particular courts will have disparate access to unpublished opinions.

\section{Judicial Accountability}

When a circuit court completely denies public access to judicial opinions, it removes an important check on judicial activity from the legal system. Public availability of judicial opinions helps to hold judges accountable to society for the decisions they reach. ${ }^{123}$ Public scrutiny helps to maintain the integrity of the judicial system and assure that individual cases are fairly decided.

Forcing judicial decisionmaking into the light of day helps not only to assure fairness in fact, but, perhaps as importantly, to promote the appearance of fairness. When a judge's reasoning in a particular case is open to public scrutiny, litigants may be less likely to believe that the decision was arbitrary or unfair. Therefore, the public availability of unpublished opinions promotes judicial accountability, which may also enhance public confidence in the legal system.

\section{Informational Importance}

The decision to prohibit dissemination of unpublished opinions also ignores their informational importance to legal consumers and scholars. Litigants may make more efficient litigation decisions if they know the court's full record in each body of law. For instance, lawyers routinely use judicial decisions in making fundamental choices such as whether to litigate or whether to appeal: "What kinds of information could litigants get from unpublished opinions that are not foreseen by the publication plans? One important piece of information is the shape of the universe of decisions ... in a particular area of law. The information might be as simple as knowing the odds." 24 An attorney may also wish to track decisions in an area of law to discern trends or to detect difficulties in the administration of a statute.

\footnotetext{
121. See supra text accompanying note 38 .

122. See Robel, supra note 38 , at 957.

123. See Reynolds \& Richman, supra note 21, at 1203-04.

124. Robel, supra note 36 , at 947.
} 
Moreover, certain types of decisions are systematically consigned to non-publication, impairing the decisionmaking of litigants in these areas of law. ${ }^{125}$ One scholar has asserted that unpublished opinions routinely result in much litigation in which the government is a party. These cases include "review of agency determinations in immigration and social security cases, Federal Tort Claims Act cases, criminal and habeas appeals, civil rights actions, and employment discrimination complaints against the federal government."126 In jurisdictions that circumscribe the public availability of unpublished opinions, litigants in these and other fields of law may be unable to obtain large quantities of relevant and useful information.

The unavailability of unpublished opinions also undermines the legitimacy of the work done by legal scholars and social scientists. A majority of federal appellate court cases are unpublished. ${ }^{127}$ Numerous studies have demonstrated that a significant number of these unpublished decisions involve cases that are non-routine, law-making, or politically significant. ${ }^{128}$ In the aggregate, unpublished opinions thus contain a great deal of valuable information about actual court behavior. The exclusion of this information may severely undermine the validity of many important scholarly studies. ${ }^{129}$ As a result, theoretical and practical insights drawn from knowledge of actual court behavior may be compromised to the public detriment.

In our legal system, which seeks the most well-reasoned resolution to legal disputes, judges are required to provide reasons for the decisions they reach. Well-reasoned analysis requires an informed decision maker. Accordingly, our rules of court should not limit the information available, but should encourage attorneys and judges to develop and perpetuate the most insightful arguments. If a court has articulated a well-reasoned or creative analysis, other decision makers can benefit from it only if they have knowledge of its existence. A system that opposes the use of unpublished opinions prevents lawyers from making their own best judgments about the relevant merits of judicial opinion, constraining the natural development of law..$^{130}$

125. See id. at $952-53$.

126. Id. at 953.

127. See, e.g., id. at $954-55$ \& $\mathrm{n} .74$ (according to the Federal Judicial Center Integrated Data Base, "the average percentage of unpublished opinions for all the federal appeals courts [for 1987] was $61 \%$ ").

128. See supra note 65 and accompanying text.

129. See Songer, supra note 12, at 313.

130. See Stephen R. Barnett, Depublication Deflating: The California Supreme Court's Wonderful Law-Making Machine Begins to Self-Destruct, 45 Hastings L.J. 519, 548 (1994). Although Professor Barnett makes this argument as it relates to California state court opinions that have been depublished, the argument would apply equally to opinions that were never published. 


\section{B. Circuit Rules on Citation to Unpublished Opinions}

In forming their limited publication/no-citation plans, most circuits chose to allow public access to unpublished opinions but to forbid their citation to the court. Recently, however, allowing citation to unpublished opinions has gained popularity. Six circuits currently allow citation, up from only two circuits in $1994 .{ }^{131}$

Within this trend toward allowing the citation of unpublished opinions, the circuits differ in their approach. Four of the six circuits emphasize that citing unpublished opinions, while allowed, is disfavored. For example, the Tenth Circuit rule on citation states in part: "Citation of unpublished orders and judgments is not favored. Nevertheless, an unpublished decision may be cited if it has persuasive value with respect to a material issue that has not been addressed in a published opinion and would assist the court in its disposition." 132 The Fourth, Sixth and Eighth Circuits similarly disfavor the citation of unpublished opinions but qualify their citation less restrictively than does the Tenth Circuit. Rather than limiting citation of unpublished opinions to issues not addressed in a published opinion, these circuits state that an unpublished opinion may only be used where "there is no published opinion that would serve as well."133 By contrast, the rules of the Fifth and Eleventh Circuits contain no qualifying language and appear to freely allow the citation of unpublished opinions. ${ }^{134}$

131. See Reuben, supra note 110 (noting that in 1994 the Tenth Circuit suspended its ban on the citation of unpublished opinions, joining the Sixth Circuit as the only two circuits to adopt such a position). The six circuits currently allowing citation to unpublished opinions are the Fourth, Fifth, Sixth, Eighth, Tenth, and Eleventh. See 4TH CIR. R. 36(c); 5TH CIR. R. 47.5.4; 6TH CIR. R. 24(c); 8TH CIR. R. 28A(k); 10TH CIR. R. 36.3; 11 TH CIR. R. 36-2. I will discuss the particulars of these rules infra.

132. 10TH CIR. R. 36.3.

133. 4TH CIR. R. 36(c); 6TH CIR. R. 24(c); see also 8TH CIR. R. 28A(k) (allowing parties to cite an Eighth Circuit unpublished opinion "if the opinion has persuasive value on a material issue and no published opinion of this or another court would serve as well").

134. The Fifth Circuit actually has two very different citation rules. Rule 47.5.3 applies to unpublished opinions issued before January 1, 1996. According to this rule, pre-1996 unpublished opinions are precedent, and "because every opinion believed to have precedential value is published, such an unpublished opinion should normally be cited only when the doctrine of res judicata, collateral estoppel, or law of the case is applicable." 5TH CIR. R. 47.5.3. By contrast, Rule 47.5.4, which applies to unpublished opinions issued on or after January 1, 1996, states:

Unpublished opinions issued on or after January 1, 1996 are not precedent, except under the doctrine of res judicata, collateral estoppel or law of the case .... An unpublished opinion may, however, be persuasive. An unpublished opinion may be cited, provided that, if cited in a brief, motion or other document heing submitted to the court, a copy of the unpublished opinion shall be attached to each copy of the brief, motion or document.

5TH CIR. R. 47.5.4. This rule thus does not qualify the circumstances in which an unpublished opinion may be cited. The Eleventh Circuit rule states simply: "Unpublished opinions are not considered binding precedent. They may be cited as persuasive authority, provided that a copy of the unpublished opinion is attached to ... the brief ..." $11 \mathrm{TH}$ CIR. R. 36-2. 
The six circuits allowing citation of unpublished opinions also differ in the level of authority they give to unpublished opinions. Two circuits appear to allow unpublished opinions to be cited as precedent, ${ }^{135}$ while the other four circuits provide that unpublished opinions may be cited only for their persuasive value. ${ }^{136}$ Important policy objectives can be served by assigning an optimal authoritative weight to unpublished opinions. As will be discussed below, courts should allow citation to unpublished opinions for their persuasive value.

\section{$\mathrm{V}$}

\section{A MODEL RULE}

Important policy considerations dictate that all judicial opinions should be subject to public critique. Accordingly, the publication plans of the various circuits should explicitly provide that all appellate opinions be made available for electronic dissemination. Further, in setting a policy on the citation of unpublished opinions, the federal circuits should allow attorneys and judges to cite to unpublished opinions when they are relevant to a material issue in the case, and give these opinions persuasive, but not binding, authority. A good example of a rule that has accomplished these goals is that fashioned by the Eighth Circuit. This rule states:

Unpublished opinions are not precedent and parties generally should not cite then. When relevant to establishing the doctrines of res judicata, collateral estoppel, or the law of the case, however, parties may cite any unpublished opinion. Parties may also cite an unpublished opinion of this court if the opinion has persuasive value on a material issue and no published opinion of this or another court would serve as well. A party who cites an unpublished opinion in a document must attach a copy of the opinion to the document.... When citing an unpublished opinion, a party must indicate the opinion's unpublished status. ${ }^{137}$

This rule best resolves the two most important questions regarding citation to unpublished opinions: In what circumstances should a party be allowed to cite an unpublished opinion and what authority should that opinion be given?

135. These are the Fourth and Sixth Circuits. After stating that their citation is disfavored, the rules of both circuits then state that an unpublished opinion may be cited "[i]f counsel believes, nevertheless, that an unpublished disposition has precedential value in relation to a material issue in a case and that there is no published opinion that would serve as well ..." 6TH CIR. R. 24(c); see also 4TH CIR. R. 36(c).

136. See 5TH CIR. R. 47.5.4; 8TH CIR. R. 28A(k); IOTH CIR. R. 36.3; IITH CIR. R. 36-2.

137. 8TH CIR. R. 28A(k). 


\section{A. Electronic Dissemination Should Be Allowed}

Making unpublished opinions available preserves the integrity of the judicial system by allowing public scrutiny of all judicial opinions. Our system provides for an independent judiciary. ${ }^{138}$ Federal judges are not elected and cannot be voted out of office. Judicial discretion is not checked by popular vote. Rather, two primary checks on appellate discretion exist. ${ }^{139}$ The first is Supreme Court review. ${ }^{140}$ Given the enormous caseload of the federal appellate courts, however, the chances for review of any given appellate opinion are very slight. ${ }^{141}$ For example, in 1993, the Supreme Court decided 163 cases-ninety-six by written opinion and sixty-seven by per curiam or Memorandum Decision. ${ }^{142}$ By comparison, the federal appellate courts in that same year disposed of more than 25,000 cases. ${ }^{143}$ We must primarily rely, therefore, upon the second check on judicial discretion.

This second check on appellate discretion is the public critique of judicial decisions by legal consumers. ${ }^{144}$ As previously discussed, the public availability of opinions helps to hold judges accountable for their decisions because they know that their reasoning and analysis will be exposed to the light of day ${ }^{145}$ For this check on judicial discretion to be effective, however, all judicial opinions must be subject to public scrutiny. This check disappears in a world where difficult decisions or faulty reasoning can be swept under the rug by not publishing an opinion, thus preventing public access. Accordingly, the courts should take advantage of current technological capabilities and make all unpublished opinions available to the public through electronic dissemination.

\section{B. Citation to Unpublished Opinions Should Be Allowed When No Published Opinion Would Serve As Well}

The behavior of legal participants and the resulting fairness considerations lead to the conclusion that unpublished opinions must be citable, at least in some circumstances. If unpublished opinions become generally available, then it makes little sense to prohibit all citation. As

138. See U.S. ConsT. art. III, § 1.

139. See Reynolds \& Richman, supra note 21, at 1202-04.

140. See id. at 1202-03.

141. These already low chances are vastly reduced if an opinion is unpublished. Given the very limited resources of the Supreme Court, the Justices focus their energy on cases that make law, not simply on redressing individual wrongs. Since the appellate publication plans have a stated goal of publishing opinions that make law, it seems significantly less likely that the Supreme Court would grant review to a case that an appellate court determined did not meet this goal.

I42. The Supreme Court, 1993 Term-Leading Cases, 108 Harv. L. Rev. 23, 376, tbl.11 (1994).

I43. 25,567 to be exact. See Statistical AbSTRACT, supra note 1.

I44. See Reynolds \& Richman, supra note 21, at 1202-04.

I45. See supra text accompanying note 123 . 
already mentioned, ${ }^{146}$ citation bans were intended to effectuate the selective publication plans. If, however, the premise underlying restrictive publication is faulty, then citation bans should be lifted.

Both evidence and common sense indicate that where potentially relevant legal information is available, attorneys will sift through that information for valuable nuggets. Even in the face of a rule barring citation, litigants can still make unacknowledged use of unpublished opinions. ${ }^{147}$ Given these and other potential uses of unpublished opinions, litigants may thus find it worthwhile to spend time researching these opinions in order to gain an advantage. If we assume, as the evidence indicates, that such behavior will occur, then the cost savings imagined by the no-citation rules will be significantly diminished. Allowing citation does not, therefore, appear to add significantly to the cost burden the rule is designed to protect.

Allowing unpublished opinions to be cited also allows stare decisis to develop naturally. For instance, while the goal of publication plans is to limit publication to opinions with precedential value, this goal is not always realized. At the time a decision is handed down, judges cannot always be absolutely certain that the decision has no future value. Judges are not superhuman and cannot see the future. Accordingly, opinions that, when written, were thought not to contain novel facts or analysis may turn out to prove beneficial to the resolution of future cases. ${ }^{148}$ When this is the case, the rules of court should not stifle the information available but rather should allow attorneys to access relevant information on the theory that a better-informed decision maker will produce better-reasoned decisions. Such relevant information is not limited to the actual language and reasoning of an unpublished opinion but also includes the credibility provided by citation-the fact that the analysis was given judicial recognition in a previous case.

This is not to say that unpublished opinions should be citable indiscriminately. The no-citation rules of the federal circuit courts seek to address the very valid concerns of cost and efficiency. Accordingly, it is appropriate for the courts to discourage the citation of unpublished opinions that are redundant or add little value to the resolution of the issue at hand. But where an unpublished opinion is relevant in a way that published opinions are not, citation should be allowed.

The Tenth Circuit limits the citation of unpublished opinions to instances where the opinion relates to a material issue that has not been

146. See supra text accompanying notes 33-35.

147. See supra notes 107-114 and accompanying text for a detailed discussion of how unpublished opinions are used despite prohibited citation.

148. For a few specific examples, see supra Part II; see also Nichols, supra note 42, at 924 (admitting being conscious of "one flagrant instance of [erroneous failure to publish] myself, but wild horses could not drag its identity out of me, and no one else has divulged it"). 
addressed in a published opinion. ${ }^{149}$ This rule is too restrictive. For instance, a published opinion may have addressed the issue at hand but with a result contrary to that achieved in the unpublished opinion. Unless the published opinion has expressly overruled the unpublished opinion on that issue, there would appear to be an intra-circuit conflict that the court should address. Courts should not restrict citation in these circumstances.

Although a model rule should force attorneys to use careful judgment when choosing to cite to a given unpublished opinion, the rule should not be too restrictive. The better rule limits citation of unpublished opinions to instances where "no published opinion would serve as well." This rule is flexible enough to allow citation to an unpublished opinion in circumstances where a published opinion has addressed the saine issue but with a different result. Allowing such citation would have a positive effect on the development of law within the circuit. It would allow opposing counsel to advance competing arguments as to which is the better legal analysis. Ultimately, the judge would be forced to decide between the competing analyses and articulate an opinion of the court.

\section{Unpublished Opinions Should Be Given Persuasive Authority}

The federal courts of appeals should allow unpublished opinions to be cited for their persuasive value only. Recall that a major reason for limiting publication is to further the goal of judicial efficiency. ${ }^{150}$ A rule that allowed unpublished opinions to be used for persuasive value would promote this goal. Where an opinion is not believed to have future precedential or analytic value, the opinion is not published. Accordingly, judges spend less time crafting these opinions than those destined for publication. Judges may provide only a cursory review of the facts and may use less careful language than they otherwise would. The hopeful result of this condensed process is that judges are more efficient and are able to handle more cases. Furthermore, attorneys are unlikely to devote as much time to researching unpublished opinions. Because these opinions are less carefully crafted, the facts may be sparse and attorneys may not rely as heavily upon them, the model rule should provide for a middle ground, allowing citation to an unpublished opinion only for its persuasive value.

149. See 10TH CIR. R. 36.3 .

150. See supra text accompanying notes $22-31$. 


\section{CONCLUSION}

The questions of whether and how publication of judicial opinions should be limited are complex. The answers to these questions involve the weighing of exceedingly important and contradictory policy considerations. Among these issues are cost and fairness concerns, judicial efficiency, judicial accountability and the role of stare decisis. In the face of these policy considerations is the stark truth that our courts are beleaguered by a colossal caseload. In the absence of more fundamental reforms designed to ameliorate this crush of cases, limited publication seems an inevitable palliative. Given the very overcrowded dockets of the federal court system, the goals served by limited publication are worth pursuing. But at what cost?

A rule of limited publication that allows for both electronic dissemination of, and citation to, all unpublished opinions for their persuasive value strikes the best balance. Such a system allows legal consumers to monitor judicial behavior, thereby promoting judicial accountability. Further, parties may cite an unpublished opinion for its persuasive value when no published opinion would serve as well. Allowing citation in these circumstances recognizes that judges cannot always foresee which opinions may have future value. At the same time, the fact that these opinions do not serve as binding precedent mitigates concerus about the less careful drafting of unpublished opinions as well as the concern that better-funded litigants will benefit because they can afford more research.

Ultimately, the analysis becomes a "balance of harms" test. Recent technology has lessened the "harms" to fairness in that the increased costs associated with more case law are less severe today than when cases were stored in the printed volume and research performed in the library. Further, allowing wide access to, and citation of, unpublished opinions advances important policy considerations. While the costs of digitally retrieving information may not yet be low enough to completely overcome fears about unfair advantage to wealthier litigants, we are moving in that direction. Case law can now be accessed over the Internet. ${ }^{151}$ Wider case law availability should lead to lower costs of access. ${ }^{152}$ Lower costs and wider access would go a long way toward easing the fairness concerns that have caused the courts to retain their

151. The Legal Information Institute, a research and electronic publishing activity of the Comell Law School, provides a good example of an Internet site featuring a broad array of legal information, inlcuding links to federal and state case law. The site is located at $\langle$ http://www.law.cornell.edu>. (Visited on Mar. 3, 1997).

152. It should also be noted that proposals in a number of states call for moving towards a vendor-neutral citation format. See supra note 74. Such a move may work to increase competition in the digital publication market. If increased competition led to lower access costs, the fairness concerns would be further eased. 
limited publication/no-citation plans. Since many unpublished opinions do indeed contain useful information and their public availability does serve important interests, courts should re-examine their selective publication and no-citation rules in light of technology's influence on legal information. 
